\title{
The Hoover-Bennett Meeting of 1931: Mismanaged Summitry
}

Richard N. Kottman

The following article represents a dimension of a larger studyCanadian policies during the Hoover Administration-to which $\mathrm{Mr}$. Kottman has devoted several years research, including considerable time in the manuscript collections in the Herbert Hoover Presidential Library at West Branch, lowa.

DESPITE THE MILD ENTHUSIASM in Canada that greeted Herbert Hoover's election as his country's thirty-first president, CanadianAmerican relations were soon subjected to centrifugal strains. ${ }^{1}$ The first, and most serious, stress followed Hoover's decision to implement his campaign pledge of greater tariff protection for the American farmer. Higher duties on important Canadian agricultural exports could only embarrass the Liberal government of Mackenzie King, arouse the ire of Canadians of all political persuasions, and afford the Conservatives an opportunity to capitalize on this public sentiment in the next general election. Repeated warnings from the United States legation in Ottawa, Canadian officials, and perceptive American journalists deterred neither the President nor Congress from a course that allegedly would reward an economic group largely denied the benefits of "prosperity decade." Frustrated in 1929 when Congress in special session adjourned without passing

\footnotetext{
"I hàve discussed very briefly the Canadian reaction to the election of 1928 in "Hoover and Canada: Dipolmatic Appointments," Canadian Historical. Review, LI (September, 1970), 292-3. An excellent analysis of the impact of this election in Canada can be found in the Times (London), November 1 , 1928. See also the editorials in the Toronto Globe of October 16 and 24 and November 2 and $7,1928$.
} 
tariff legislation, Hoover finally affixed his signature to the Smoot-Hawley Tariff Act in June, 1930, confident that a reorganized, bipartisan Tariff Commission, exercising the power given it in the new law to recommend tariff changes to the President when circumstances warranted, would placate foreign export interests momentarily disenchanted with the revised (and perhaps excessive) rates. ${ }^{2}$

What Liberals in the dominion had feared-and diplomats had predicted-came to pass. Riding the rhetoric of their leader R. B. Bennett who assured his countrymen that higher Canadian tariffs would mean more effective bargaining with other commercial powers, capitalizing on the contempt in which Canadians held Smoot-Hawley, and exploiting several indiscreet campaign statements of Mackenzie King, the Conservatives prevailed in the election of July, 1930, and immediately set out to raise dominion schedules higher than those of the Dunning Budget of May, the Liberals' retort to congressional caprice. In September, at a special session shortened by the Prime Minister's departure to London for an Imperial Conference, Parliament revised upward selected, but important, duties. Through modifications in the Customs Act, Parliament also granted arbitrary powers to the minister of national revenue to valorize imports for duty purposes. Worse, general tariff revision with its threat to American sales in Canada was scheduled for $1931 .^{3}$

Shortly after his inauguration, too, Hoover reversed the lax prohibition enforcement policies of his predecessors, requiring the Department of State once again to press the King government to embargo shipments of liquor from Canada to the United States. For a year Ottawa resisted the pressure, believing that the importation of

${ }^{2}$ For some important citations dealing with the efforts before the passage of the Smoot-Hawley Tariff Act to dissuade Hoover and Congress from passing tariff legislation, see Kottman, "Hoover and Canada: Diplomatic Appointments," CHR, LI, 294, n. 3. For the first direct Canadian plea-Sir Henry Thornton, King's emissary to Washington in March, 1929, in private conversation with Hoover-see memorandum, Thornton to King, March 16, 1929, Mackenzie King Papers, Public Archives of Canada, Ottawa, MG 26 J I, vol. 169. Hoover explained his decision to sign the Smoot-Hawley bill with its emphasis on the tariff flexibility feature in The State Popers and Other Public Writings of Herbert Hoover, Collected and edited by William Starr Myers, (2 Vols., Garden City, New York, 1934), 1, 102-4, 318.

${ }^{3}$ For a very general account of these legislative actions, see The Canadion Annual Review of Public Affairs, 1930-31 (Toronto, 1931), 35-42, hereafter cited as Canadian Annual Review. 
Canadian liquor had little effect on America's "wetness" or "dryness" and that such a measure, besides costing the dominion revenue and the taxpayer increased assessments, would place on Canada the onus for failure if, as officials assumed, the traffic continued. Moreover, public opinion divided sharply on this issue of Canadian cooperation in American prohibition enforcement, and remained anxious about the tariff debate on Capitol Hill. Not until January, 1930, did King decide definitely that international goodwill dictated Parliamentary action, that a majority of Canadians now agreed with this course, and that the Hoover Administration, as reflected most recently in the establishment of a border patrol to battle against smuggling, sincerely favored more rigid enforcement. In March he personally introduced the desired legislation, and in late May, just two weeks before Congress raised American tariff schedules, the bill became law. ${ }^{4}$

Despite the change in government, the law was not repealed, although there were efforts in subsequent parliamentary sessions to do so. Hanford MacNider, the American Minister in Canada, dismissed such talk as little "more than a bluff on the part of Members of Parliament in districts adversely affected by our new immigration tactics." Smuggling activities by Canadian rum runners willing to risk an encounter with the United States Coast Guard continued. On January 24, 1931, in action reminiscent of the I'm Alone affair of April, 1929, the Coast Guard ended abruptly the ventures of the previously elusive Josephine $K$., sinking the vessel and fatally wounding its captain. ' Since the circumstances' of the interception were marginal, the two governments had another international incident to resolve.

The demands of organized labor in the United States, more strident in late 1930 because of the Great Depression, precipitated

"For a detailed treatment of this subject, see Richard N. Kottman, "Volstead Violated: Prohibition as a Factor in Canadian-American Relations," Canadian Historical Review, XLIII (June, 1962), 106-26.

${ }^{5}$ MacNider to James L. Wright, February 5, 1931, Hanford MacNider Papers, Herbert Hoover Presidential Library, West Branch, lowa.

'Pertinent doucments relating to the sinking of the fosephine $K$. can be found in Foreign Relotions of the United States: Diplomatic Papers, 1932 (5 Vols., Washington, 1947), II, 78-92. The latest scholarly treatment of the I'm Alone incident is M. Paul Holsinger, "The 'I'm Alone' Controversy: A Study in Inter-American Diplomacy, 1929.1936," Mid-America, L (Oct., 1968), 305-13. 
another issue, the American maneuver to restrict entry into the country of commuting workers from Canada. That the dominion, as acutely affected by the economic collapse as the United States, had chosen not to take similar action against American commuters made the issue that much more annoying. ${ }^{\text {? }}$

Canadian wheat growers and dealers, faced with surpluses estimated at 250,000,000 bushels and no apparent market, had their grievances. The purchase of wheat by the Grain Stabilization Corporation with funds allocated to it by the Federal Farm Board in Washington had raised slightly price levels in the United States. In the absence of a comparable dominion agency; wheat prices in Canada were abysmally low. As a result, the Prime Minister was under pressure to find some way to alleviate this condition. ${ }^{8}$

From Washington's standpoint, the outstanding problem was the refusal of Canada to proceed with the joint development of the St. Lawrence River between Montreal and Lake Ontario. Hoover's pet project since the mid-twenties when he chaired the St. Lawrence River Commission, the seaway had been delayed for years by the procrastinations of Mackenzie King and, more recently, by the idiosyncrasies of R. B. Bennett who as prime minister established a virtual one-man government in Ottawa, unwilling or unable to delegate many responsibilities to subordinates. Hoover had expressly commissioned Hanford MacNider to conclude a waterway treaty. By January, 1931, he had nothing concrete to show for his efforts, only the promise that Bennett would study the question upon his return from the Imperial Conference.?

${ }^{7}$ For background to this issue, see Papers Relating to the Foreign Relations of the United States, 1927 (3 Vols., Washington, 1942), 1, 494-511; for developments in late 1930 and 1931, see Papers Relating to the Foreign Relations of the United States, 1931 (3 Vols., Washington, 1946), 1, 894-8. The problem is reviewed as well in Canadian Annual Review, 1930-31, 358-60.

${ }^{3}$ Christian Science Monitor, January 28 and 30,1931 . See also the discussion of the wheat problem, particularly its Canadian overtones, in Survey of International Affairs, 1930 (London, 1931), 477-81. Albert U. Romasco discusses the American governments attempts to stabilize wheat prices in The Poverty of Abundance (New York, 1965), 115-17.

${ }^{9}$ William R. Willoughby, The St. Lawrence Waterway: A Study in Politics and Diplomacy (Madison, Wisconsin, 1961), 97-137. Bennett's proclivities for one-man rule are developed in Kottman, "Hoover and Canada: Diplomatic Appointments,", CHR, LI, 305-6. Sir William Clark, the British High Commissioner in Ottawa, corroborated that Bennett expected "his ministers to act merely in a secretariat or advisory capacity." During the parliamentary 
Against this backdrop of deteriorating relations, in late January, 1931, Bennett came to the American capital on an informal and unofficial visit, during which he met with President Hoover and several other Washington officials. One might think that the meeting of two men so similar in background and outlook would produce, if not significant diplomatic breakthroughs, at least a friendship that would provide the bilateral tie with a meaningful new dimension. Bennett was a wealthy man who, like Hoover, traced his good fortune to his own efforts and ability; like Hoover, he believed in protection as a means by which his country could attain economic greatness; like Hoover, he assigned to government a passive role in the economy much preferring to see business function with a minimum of regulation; and like Hoover, he did not take kindly to criticism from the "fourth estate." Nevertheless, the two heads of state failed to effect any kind of warm and workable relationship. Their personal meeting contributed little, if anything, to a settlement or an understanding of each other and their national differences. It ended, moreover, on a sour note for both Bennett and the American journalists who talked with him.

This unsuccessful experiment in "summitry" or personal diplomacy suggests the limitations of this alternative to traditional procedures, particularly if no preparations by the respective foreign. offices have been made. Preparations were certainly lacking in this instance. Apparently, Bennett had not even divulged to the Cabinet what topics he expected to discuss with the President. ${ }^{\circ}$ Neither the files of the Department of State nor the records in the presidential papers disclose any memorandum briefing Hoover on items that might arise in his conversations with the Prime Minister. However,

session of 1931 Bennett was "fully determined with unbounded self-confidence to conduct a 'one-man government' in the full sense of the word. Nothing is too great or too small for him to deal with personally." Clark personaliy had seen "the enormous volume of work with which Mr. Bennett deals daily and ... his refusal to delegate any of it either to other Ministers or to a Secretariat of his own." William Clark, High Commissioner, to Dominion Office, No. 67, April 8, 1931, British Foreign Records, Public Record Office, London, File F. O. 627/ 34, document U339/127/750. To William R. Castle, Jr., MacNider referred to the "very definite mission" given him by the President. MacNider to Castle, October 14, 1930, MacNider Papers. The Canadian note of September 10,1930, promising study upon Bennett's return from London is printed in Papers Relating to the Foreign Relations of the United States, 1930 ( 3 Vols., Washington, 1945), 1, 533.

10 Toronto Globe, January 29, 1931. 
the decision to shroud in secrecy Bennett's several private talkswith Hoover, secretaries Stimson, Lamont, and Wilbur and Eugene Meyer, Jr., Governor of the Federal Reserve Board-encouraged speculation about their importance, leading a Canadian journalist to aver that the discussions "covered a wide territory and that events of moment may be in the air." "When salutary expectations did not materialize, relations deteriorated further. Hoover became annoyed, feeling that his guest had not kept a promise to act promptly on his St. Lawrence seaway proposal. Bennett disliked the press coverage attending the visit, believing that it misled the public into thinking that momentous conversations were being held.

The visit was mismanaged from the beginning. That the Prime Minister even planned to go to Washington prompted members of the press, in both Canada and the United States, zealously to determine the "real" reason for the trip south. They refused to accept at face value Bennett's public explanation that he had come to inspect the Canadian legation and, as minister of External Affairs, to meet Hume Wrong, the Canadian Chargé d'affaires, and his staff. As David Rankin Barbee of the Washington Post expressed it, "that he came to match wits with the best minds now in power in this country; that he had a program of 'sore spots' to talk over is apparent to any one who can see to the tip end of his nose ..." ${ }_{12}$ Embarrassingly, news of the imminent visit had become public in Washington before Bennett's announcement in Ottawa, after "every effort" had been made by State Department and legation officials "to keep the plan secret, officials of both declining to comment when a report regarding it" circulated in the capital. " 3 Hume Wrong apologized to the Prime Minister, claiming to have done everything possible to prevent it. "I think the leak must have come from the White House," Wrong continued, "which is notoriously uncertain in these matters." " William R. Castle, Jr., assistant secretary of state, thought differently. "I know as well as I can know anything without documentary proof," he wrote MacNider, "that the Associated Press

1 /bid., February 2, 1931.

12 Washington Post, February 1, 1931. See also the Associated Press dispatches announcing the visit in the Chicago Tribune, January 24, 1931, and the Washington Post, January $24,1931$.

${ }^{13}$ Washington Post, January $24,1931$.

14 Wrong to Bennett, January 24, 1931, Richard B. Bennett Papers, Harriet Irving Library, University of New Brunswick, Frederiction, voi. 275. 
got that news from the Canadian press.... This matter of leaks to the press has interested me for a long time, and I have been trying hard to get some line on it." 1 s Whatever the explanation, Wrong noted that the curiosity of the press had been aroused, and that particular attention would be paid to the White House meeting between Bennett and Hoover if that fact became known "as I am afraid it will be before you arrive." To limit the conjectures, Wrong advised the Prime Minister to hold a press conference during the visit." " With nothing to guide them, newsmen speculated that the two heads of government would focus on such questions as the sinking of the Josephine $K$., the liquor problem in general, the commuting annoyance, wheat surpluses, tariffs, and, most important of all, the St. Lawrence waterway." '

On January 30, 1931, the day of Bennett's arrival, Secretary of State Henry L. Stimson found reporters at his regular press conference to be "terribly excited" about what subjects he and the Prime Minister planned to discuss. Despite their interest, however, they "didn't get anything" from him. In the early afternoon Stimson met his guest at Union Station, and drove him to Wrong's home. Then and later that day the two men chatted pleasantly, Stimson subsequently referring to Bennett as "a very likable fellow." Ever mindful of the suspicions of the reporters, Stimson met with them again shortly after the Prime Minister's visit to his office "to assure them what he [Bennett] had not said." According to the Secretary, none of the major questions had been mentioned.' 8 Bennett also

${ }^{15}$ Castle to MacNider, February 16, 1931. William R. Castle, Jr., Papers, Herbert Hoover Presidential Library, West Branch, lowa, Box 2, claimed that Canadian reporters got news that they were not allowed to use and, in turn, gave it to their friends among the American press corps. The Canadians were safe in conducting themselves in this manner because "no press man will ever admit where he got any specific piece of information."

${ }^{16}$ Wrong to Bennett, January 24, 1931, Bennett Papers, Vol. 275.

17 The Christian Science Monitor, January 28 and 30, 1931, focused on the twin issues of wheat and the waterway. A headline in its January 28 issue read, "Bennett Visit to Hoover Thought to Have Much to do with Wheat Situation." The gamut of issues that would likely be discussed can be found in the Washington Post, January 30, 1931, New York Times, January 30, 1931, Chicago Tribune, January 24, 1931, and Toronto Globe, February 2, 1931.

1 Entry of January 30, 1931, Stimson Diary, Vol. 15, Henry L. Stimson Papers, Sterling Memorial Library, Yale University, New Haven, Connecticut, Stimson's public disclaimer is reported in Chicago Tribune, January 31, 1931, and the Boston Evening Transcript, January 31, 1931. 
talked briefly with President Hoover at the White House, after which the latter declared that they had "no formal matters under discussion." The two leaders were "mutually interested in the common welfare of both nations," Hoover added, and doubtless would have "some informal conversations on problems of the future." 9

That evening Bennett dined at the White House in the company of Hoover, Stimson, Wrong, MacNider, Castle, and Major William Herridge, a close friend and traveling companion of the Prime Minister, who was soon to become the Canadian Minister to the United States despite a disclaimer during Bennett's press conference. Following dinner, Hoover and Bennett retired to a corner of the library and talked "vigorously" for about ninety minutes. Later, when his guests had departed, the President called the Secretary of State aside, and informed him that they had discussed minor irritants, including the latest American restriction on Canadian commuters, before turning to a more important topic, the St. Lawrence seaway, a topic Bennett was reluctant to discuss. When they finally did, Bennett said that the political climate in Canadamade more troublesome by Canadian-American "difficulties"prevented him from proceeding with any "treaty-making project." As an alternative, Hoover suggested the creation of a commissionwith from three to five eminent persons from each country-not to draft an accord but to discuss freely and critically the merits of the concept. It would then publicize a proposed plan based on its inquiry which would hopefully attract and crystallize opinion in support of the seaway. Bennett, reluctant even on this point, refused to commit himself, only agreeing to communicate with the State Department in such language that the President could forward his suggestion to Ottawa where "he would consider it favorable and do his best for its acceptance." 20 The item of paramount concern to

19 The newspapers already cited carried Hoover's press conference statement in its entirety. The original is in the Hoover Papers, Press Conferences of Herbert Clark Hoover, I-G/ 380, press conference of January 30, 1931.

${ }^{20}$ Entry of January 30, 1931, Stimson Diary, vol. 15; memorandum of conversation between Marriner and MacNider, January 31, 1931, Department of State Records, National Archives, Washington, D.C., File No. 611.616/187. Actually, Hoover gave two versions of his conversation. To Stimson immediately following Bennett's departure, he said that the Prime Minister introduced the subject and "seemed to be much taken" with Hoover's proposal. To MacNider, and I think this is the correct account, the President 
Bennett, however, was the Soviet Union's commercial threat to Canadian wheat and lumber exports: The large-scale sale of these commodities, an integral part of the grandiose Five Year Plan to transform the Soviet economy into an industrialized giant, would further depress the market. Quite naturally, Bennett wanted the United States and the dominion to cooperate to "resist Russia on this." The President responded tepidly, feeling that to be effective, a multilateral effort was needed. The conversation ended with Bennett's revealing several confidences allegedly implicating the Soviets in the financial affairs of the last election campaign in Great Britain. ${ }^{2}$

The two men had not established any kind of warm, mutually agreeable relationship. From Hoover's standpoint the test was Canadian cooperation on the seaway. Here Bennett had agreed to nothing concrete. Similarly, Bennett had gotten no satisfaction on the question that irritated him. Other issues-wheat sales and tariffs-had apparently not been discussed exhaustively.

Whereas the exchange between Hoover and Bennett had been cordial, if not productive, other developments surrounding the visit left a residue of bitterness in Ottawa and among American newsmen. On January 31 Bennett met with a group of Canadian and American journalists. His performance annoyed those present, leading an Associated Press reporter to write, "Evading every question put to him, the Premier concluded the conference... with a brief statement of which he forbade publication.... The Premier gave no direct answers to any of the questions..."22 He set the tone with

noted Bennett's reluctance to talk about the seaway at all as well as his reluctance to commit himself on the commission proposal.

21 Entry of January 30, 1931, Stimson Diary, Vol. 15. For a brief treatment of Soviet behavior and motivations, see Max Beloff, The Foreign Policy of Soviet Russia, 1929-1941 (2 Vols., London, 1963), 1, 27-45. The most recent and detailed account of economic friction between the Soviet Union and Canada during the early thirties is Aloysius Balawyder, Canodian-Soviet Relations Between the World Wars, (Toronto, 1972), 118-148. Unfortunately, the dispatch from Sir Ronald Lindsay, the United Kingdom ambassador in Washington, reporting a conversation with $R$. B. Bennett during the latter's visit to the American capital is no longer in the files of the Foreign Office.

${ }^{22}$ The Sunday Star (Washington), February 1,1931 , and the Washington Post, February 1, 1931, published this controversial AP dispatch. The pertinent section is as follows: "The confusion and uncertainty which has surrounded the visit ... [ of Bennett to Washington] deepened last night as he prepared to return to Ottawa. A conference with newspapermen arranged to 
his response to the first question. "What about the St. Lawrence?" asked a reporter, to which Bennett, smiling, replied, "It is still there." When pressed about the conversations with Hoover, the Prime Minister testily remarked that "it was his custom to disremember after-dinner discussions." ${ }^{3}$ One participant, James L. Wright of the Buffalo (N.Y:) Evening News, wrote MacNider that "the Prime Minister made a botch of his press conference, and left anything but a happy impression" on those present. "We do not like to have any man assume a patronizing air, tell us in a newspaper-boy attitude that he knows we have to 'manufacture news' ..." Wright elaborated, "he invited questions and then ridiculed all that were asked. It was an attempt at none-too-friendly wise-cracking. His remarks were cynical. He could have said at the outset that he could not discuss international questions, and that would have ended the matter." 24

Speculation and rumors abounded, even after Bennett's return to Ottawa. "The papers up here are very much upset because they have been given no news about the expedition," the Minister revealed to Wright, "and I have just spent a couple of hours trying to fend off a lot of newspapermen up here." MacNider concluded, "I only hope they treat me kindly because I could give them no information and I know they felt I had a lot." 25

Whereas reporters reacted negatively to Bennett, the Prime Minister had his own complaints. Within a month of his return, relations between the Canadian government and the Associated Press had become seriously strained because of the actions of one of the syndicate's journalists. On the day of his departure from Washington, Bennett asked Hume Wrong to inform Frank B. Noyes,

give the premier an opportunity to talk frankly on the discussions he has had with American officials, served only to add to the speculation over the visit. Evading every question put to him, the premier concluded the conference with newspapermen at the Canadian legation with a brief statement of which he forbade publication. Questions relating to the proposed St. Lawrence waterway, liquor, the Josephine $K$. incident, wheat, and finances were turned aside by the premier with responses such as 'Now, that's an interesting point,' and 'your question suggests something to me that I should look into.' The premier gave no direct answers to any of the questions put to him by a group of some 30 Canadian and American newspaper men about Canadian-American problems...."

23 Toronto Globe, February 2, 1931.

24 Wright to MacNider, February 3, 1931, MacNider Papers.

25 MacNider to Wright, February 5, 1931, ibid. 
president of the Associated Press and owner of the conservative Washington Evening Star, of his displeasure with the way in which his visit had been treated by the organization, a displeasure he expressed again en route to New York from Washington. ${ }^{26}$ Unable to convey Bennett's thoughts to Noyes orally, Wrong after a delay of several days did so by letter. Shortly before Bennett's arrival in Washington, Wrong with great care had briefed several newspapermen, including the AP reporter assigned to cover the visit, that the Prime Minister had come to inspect the Canadian legation, but expected to meet Hoover and Stimson. Once in the American capital, however, Bennett "was surprised to find that not only were his footsteps dogged wherever he went... [by the reporter in question] but that his frank statement on the purpose of his visit, which he had repeated with emphasis at a press conference ... was treated with incredulity." Moreover, before the arrangements for Bennett's visit had been concluded, the AP had learned of the Prime Minister's imminent departure and had published this information in spite of appeals from both the Department of State and the Canadian legation to withhold the release until Bennett himself had made the announcement. ${ }^{2}$ ?

Undeniably the reporter pursued his duties diligently. During his meeting with several journalists mentioned above, Wrong in some detail had explained why they could not press him for information about the Prime Minister's plans, particularly the scheduled social engagements in Washington. When the Chargé arrived at the station in Baltimore to meet Bennett, he saw the AP reporter who startled him with the request that Wrong arrange for hima an interview with the Prime Minister to be conducted while the Canadian party was traveling from Baltimore to Washington. Wrong expressed doubts. about Bennett's willingness to hold this type of interview, but agreed to inform the Prime Minister that the gentleman was on the train. If Bennett wanted to go on from there, Wrong promised to contact him. The reporter subsequently entered the Prime Minister's car uninvited. Even this "unjustifiable intrusion" was not all. He had talked on the telephone with one of the legation staff, "threatening" to "follow Mr. Bennett wherever he went unless the legation would furnish him with details of his programme." When it refused, the

26 Wrong to Bennett, February 21, 1931, Bennett Papers, Vol. 275.

27 Wrong to Noyes, February 5, 1931, ibid. 
persistent reporter carried out the threat, and, in Wrong's words, "followed Mr. Bennett's car whenever he left the legation, and stood outside the building at night until the lights were extinguished." That "no other journalist thought it necessary to adopt these devices" underscored for the Canadians the "legitimate cause of irritation." 28

Distorted reporting also drew fire. As Wrong wrote Noyes in his initial letter, "every AP report which I have seen was filled with rumours of mysterious and quite non existent negotiations which were alleged to have taken place." 29 The Chargé conceded AP dispatches were no more misleading than some, and less so than others. Not surprisingly, they were very complete in chronicling details of Bennett's movements. Nevertheless, the reporter's suggestion that important negotiations were going on embarrassed the government, and prompted other journalists to question the Prime Minister's stated reason for coming to Wäshington. ${ }^{30}$

The Canadian complaints to the president of the AP provoked develonments perhaps novel in the history of Canadian-American relations. Frank B. Noyes immediately turned Wrong's letter over to Kent Cooper, the syndicate's general manager, who took the offensive. He noted that because of Bennett's "singular aversion to the press," his organization had "reduced its news coverage of his visit to the lowest point compatible with its obligation to every daily newspaper published in Canada and 1300 newspapers in the United States." He denied that statements in AP dispatches were misleading; in fact he argued that "every statement... [was] confirmable by reliable authority." Disputing Wrong's allegation that the AP reporter treated Bennett's comments with "incredulity," Cooper described as perplexed his own reaction to the Prime Minister's remarks, particularly his denial of discussions of consequence with American officials when Hoover had referred to "informal conversations on problems of the future." Moreover, Cooper failed to see any breach of professional ethics in any of the actions, but admitted that he and Wrong disagreed on the point. He emphasized that Wrong's complaint was unique in a career that had spanned thirty years, but

\footnotetext{
${ }^{28}$ Wrong to Noyes, draft letter, March 2,1931, ibid. The letter in this form was never sent.

${ }^{29}$ Wrong to Noyes, February 5, 1931, ibid.

${ }^{30}$ Wrong to Noyes, draft letter, March 2, 1931, ibid.
} 
promised, nevertheless, to forward Wrong's letter, and any additional correspondence the Chargé chose to send, to the board of directors of the Associated Press. ${ }^{3} 1$

Wrong's reply was prompt and succinct. The Chargé stated that he did not want to become involved in an epistolary exchange, and suggested that the two men discuss the question during Cooper's next trip to Washington. Noyes himself then kept the incident alive with a most intemperate letter to Wrong. Reporting this latest wrinkle to the Prime Minister, the Chargé admitted that Noyes' letter had "got very much under my skin, and I am probably taking it too seriously." The thought that "it is probably to the advantage of the Prime Minister of Canada to have a critical press in the United States" consoled him. It left, however, "a very nasty taste in my mouth ... and I think that I was probably over-zealous in carrying out your instructions.",32

By early March, Wrong had drafted a long letter to Noyes spelling out the main charges against the AP reporter and refuting Noyes' own "insulting" attempt to defend the organization. ${ }^{3}{ }^{3}$ Before mailing it, however, the Chargé decided to solicit the advice of a friend, Sir Willmott Lewis, the Washington correspondent of the Times (London). Lewis, Noyes' son-in-law, reportedly had considerable influence with the AP executive. Wrong was particularly interested in whether Noyes might publish his scathing note to the Chargé. Initially reluctant to be drawn into the dispute, Lewis changed his mind after Wrong read him Noyes' letter. He promised to see Noyes at his first opportunity to try to compose the difficulty. It was obvious to Lewis that his father-in-law had drafted the letter "when in a furious temper." He doubted that the letter would be made public, even though the complaints would have to be reviewed by the board of directors of the AP. In any case, Lewis stated that Noyes had recently mellowed, but still believed that the AP dispatches were at least on a par with others, and in some cases had spiked rumors that were gaining currency, a point Wrong was willing to concede. A second bone "sticking in Noyes' throat" was an alleged threat made by Wrong to the AP reporter that the ibid.

${ }^{31}$ Noyes to Wrong, February 7,1931 ; Cooper to Wrong, February 9, 1931,

${ }^{32}$ Wrong to Bennett, February 21, 1931; Noyes to Wrong, February 17, 1931, ibid.

${ }^{33}$ Wrong to Noyes, draft letter, March 2, 1931, ibid. 
Canadian legation would henceforth discriminate against the syndicate.

His two meetings with Lewis convinced Wrong to withhold his sharply worded rebuke of Noyes. A narration of events, as originally conceived, "would only provoke a long reply in kind." ${ }^{4}$ On March 12 the Charge' sent Noyes a more carefully phrased reply. He absolved Bennett of any responsibility for the language used to express the Prime Minister's complaints. The Chargé denied any intention on his or Bennett's part "to make any attack on the Associated Press as an organization," while admitting that his letter "seems to have conveyed that impression and also the impression that I believed that the dispatches of the Associated Press were particularly misleading." Wrong conceded that the dispatches in question were no worse, and in some respects better, than those of other journalists. His major grievance remained the activities of one reporter "whose zeal... outran his discretion." Wrong explained that several days after Bennett's departure from Washington he reported to the journalist the substance of Bennett's complaint. When so advised, the reporter defended his actions, adding that he "should have pursued the same methods further." At that point Wrong declared that in the future he "should feel justified in seeking to place obstacles in his way." That statement was not to be construed as a blanket threat against the AP for, as Wrong wrote, "I shall be happy to co-operate with the Associated Press in the future as in the past." Whereas the tone throughout had been conciliatory, the Chargé concluded, "some of the observations made in your letter you must permit me to pass over without comment or reply."

Noyes still would not let the affair die. He asked Wrong if, after reading the full text of the AP report of the Bennett visit, the Chargé still felt justified in his allegation that it was "full of rumors of non-existent negotiations" and a distortion of what had transpried. ${ }^{36}$ Wrong answered that his "language was too general," but argued that news stories alone would not have prompted the complaint. He still took exception to several parts of the AP dispatch of January 31, reiterating that Bennett came to visit the

\footnotetext{
${ }^{34}$ Wrong to Bennett, March 2, 1931; Wrong to Bennett, March 13, 1931, ibid.

${ }^{35}$ Wrong to Noyes, March 12,1931, ibid.

${ }^{36}$ Noyes to Wrong, March 19, 1931, ibid.
} 
Canadian legation prior to his appointment of a minister to the United States and that the conversations between Hoover and Bennett were too general to be the subject of a press communique. $^{37}$

Noyes immediately interpreted Wrong's latest statements as "a withdrawal of your previous indictment of the integrity of the news reports of the Associated Press." He advised further that unless he heard otherwise from the Chargé, he would so inform the board of directors. $^{38}$ In a draft letter Wrong answered the arguments advanced by Noyes to resolve the outstanding "minor points"-such as the ethics of the AP release of the impending visit before official notice was made in Ottawa-but he never sent it. Noyes' interpretation was allowed to stand.

On April 1 Wrong forwarded his draft to Bennett, noting that the Prime Minister could terminate the controversy by accepting Noyes' comments as the final word, prolong it by sending Noyes the enclosure in which Wrong had documented that the AP correspondent had lied on one specific occasion, or become involved himself by personally writing Noyes. Wrong saw no pressing need for the third course, since he had "succeeded fairly well in focusing on.. [himself] the resentment which the matter had aroused in the minds of Mr. Noyes and his colleagues, and ... they now regard me and not you as the villain in the piece." ${ }^{\prime 39}$ That rationale, strengthened by the assurances of Sir Willmott Lewis that the episode would receive no publicity and Noyes considered the incident closed, probably explains the decision to let the matter rest.

Beyond this intriguing glimpse of the ethics and maneuvers of the journalism profession remains the inability of Bennett and Hoover to improve relations through personal diplomacy. The visit was not a grand success. Their impressions of each other are unknown. That they never met again-and did not even correspond -perhaps says something. Bennett left Washington with some resentment at the treatment accorded him by the press and with no satisfaction regarding his efforts for Canadian wheat growers. Hoover wanted action from the Prime Minister on the St. Lawrence waterway question; none was immediately forthcoming. Personal

${ }^{3} 7$ Wrong to Noyes, March 26, 1931, ibid.

${ }^{38}$ Noyes to Wrong, March 30,1931 , ibid.

${ }^{39}$ Wrong to Bennett, April 1, 1931, with enclosure, draft letter Wrong to Noyes, March 31, 1931, ibid. 
diplomacy had failed to change the direction in which CanadianAmerican relations had been heading for the past two years. Higher Canadian tariffs and the Anglo-Canadian trade agreement of 1932, negotiated at the Imperial Economic Conference held in Ottawa with the intention of diverting commerce from American to imperial channels, lay ahead to the consternation of American business. Dominion exporters of lumber and copper felt significantly the impact of the Revenue Act of 1932 when Congress, manifesting a commitment to the sanctity of balanced budgets, imposed excise taxes, in addition to the pertaining tariff rates, on these two products.

On February 6, a few days after Bennett's return to Ottawa, stories appeared in the press that one result of the meeting in Washington was the imminent appointment of a preliminary commission to expedite completion of the St. Lawrence waterway negotiations. ${ }^{40}$ Such reports proved to be erroneous. Not until November, 1931, were negotiations begun, and then by State Department personnel and William Herridge rather than by ad hoc commissioners. Not until July, 1932, was a seaway treaty perfected, much too late to alter Hoover's image in Canada or to dissuade Conservatives from their apparent preference for a victory by the Democrats in the presidential election.

Given the timing of Bennett's trip to Washington-shortly before the opening of an important session of Parliament- ${ }^{41}$ the recent deterioration in Canadian-American relations with numerous questions still unresolved, and the prominent individuals who had audiences with Bennett, it is understandable why reporters felt there was more to the visit than they had been told. Their efforts to discover this greater meaning-or the tendency to let their speculative faculties run riot-created problems for the participants, and

${ }^{40}$ Christian Science Monitor, February 6, 1931; New York Times, February $6,1931$.

41 Toronto G/obe, January 29, 1931, published dispatch by a staff correspondent. It stated that Mackenzie King had issued a statement complaining about Bennett's failure to summon Parliament to deal with the nation's economic ills. He chided him about the trip to Washington just at that time, and posed rhetorically, "I wonder what would have been said if, before meeting Parliament at a time of serious economic distress, I had, while in office, found it necessary to go to Washington for an interview with the President of the United States, or, indeed, for any other reason." King's statement may be found also in Canadian Annual Review, 1930-31, 31. 
aroused the expectations of informed citizens in both countries. Meetings between heads of state, formal or informal, carry the risk that the leaders cannot properly and successfully negotiate or exchange views in this public setting. When they leave such talks empty-handed, there follows the inevitable disappointment, if not disillusionment. The technique can only succeed when the foreign offices have composed the various problems and have ready for ratification, by their heads of state, agreements on these outstanding issues. Inadequately planned summit meetings-such as the BennettHoover meeting of 1931-can easily be mismanaged or misconstrued. At best they do little good; they can do great harm. The ultimate verdict of the Bennett-Hoover summit is mildly negative-no disastrous consequesces but no significant improvement in relations. It remains an excellent example of how not to arrange and to conduct such a meeting.

The Sioux of the Rosebud Photographs by John A. Anderson, Text by Henry W. Hamilton and Jean Tyree Hamilton (Norman: University of Oklahoma Press, 1971), pp. XXXI, 320, index. $\$ 12.50$

THIS IS A HISTORY in pictures of the Brule Sioux Indians on the Rosebud Reservation in South Dakota. The book presents photographs taken by John A. Anderson, a Swedish-born settler who migrated west to Fort Niobrara, Nebraska in 1883. Anderson's interest and proficiency in photography led to his being invited by the U.S. army to serve as official photographer to the Crook Treaty Commission's visit to the Brule Sioux Indians on the Rosebud Reservation in South Dakota. From 1891 until his death in 1948, Anderson lived on the Rosebud and recorded the painful adjustment of the proud Brulés to life on the reservation.

The text by Henry W. and Jean Tyree Hamilton offers explanation and documentation of the persons, places and events in Anderson's photos. Also included is a brief biography of Anderson and a brief account of the Brulé Sioux. 
Copyright of Annals of Iowa is the property of State of Iowa, by \& through the State Historical Society of Iowa and its content may not be copied or emailed to multiple sites or posted to a listserv without the copyright holder's express written permission. However, users may print, download, or email articles for individual use. 